\title{
Highway Project Value of Money Assessment under PPP Mode and Its Application
}

\author{
Xiaowei Hu (iD) ${ }^{1}$ and Juan Han ${ }^{2}$ \\ ${ }^{1}$ School of Transportation Science and Engineering, Harbin Institute of Technology, Harbin 150090, China \\ ${ }^{2}$ Highway Survey and Design Institute of Heilongjiang Province, Harbin 150080, China \\ Correspondence should be addressed to Xiaowei Hu; xiaowei_hu@hit.edu.cn
}

Received 26 February 2018; Revised 9 July 2018; Accepted 31 July 2018; Published 15 August 2018

Academic Editor: Zhi-Chun Li

Copyright ( 2018 Xiaowei Hu and Juan Han. This is an open access article distributed under the Creative Commons Attribution License, which permits unrestricted use, distribution, and reproduction in any medium, provided the original work is properly cited.

\begin{abstract}
The application of Public-Private Partnership (PPP) mode in transportation infrastructure construction has achieved more progress worldwide; now this mode has been adopted in highway projects of China from 2015. In the application of PPP mode, there are three main facts in China, which include whether the government is responsible for land acquisition and resettlement (LAR), the discount rate changes, and the replacement of business tax by value-added tax (VAT) in 2016. So this paper discusses Value for Money (VFM) quantitative assessment of highway projects under PPP mode in China, which considers currently three actual issues in China. A case study of Heda freeway in China has shown that (1) the government's responsibility for LAR compensation may attract social capital investor and reduce the risk of social instability, (2) a reasonable range of a low discount rate can greatly reduce government expenditure, and (3) the replacement of business tax by VAT will increase the highway project company's burden. The research results will be helpful for value of money assessment of highway projects under PPP mode in China and may offer the reference for other countries' highway projects under PPP mode.
\end{abstract}

\section{Introduction}

The concept of Public-Private Partnership (PPP) was first proposed by England government, while the early designation was called Private Finance Initiative (PFI), which can be found in Fox and Tott [1]. In 1992, the England government passed a legislation to promote the application of PFI mode [2], and with the accomplishment of a batch highway infrastructure projects, authority and scholars in England summarized the new progress and experience of PFI. In 2004, England government issued Value for Money (VFM) Assessment Guidance [3] and put forward using VFM assessment method to evaluate public projects. Value for Money Assessment Guidance was updated in 2006 [4], while, in 2012, HM Treasury [5] published a new approach to Public-Private Partnerships, which is also based on the VFM method. PPP mode can not only help the government public sector to avoid financial risks and promote private investors to participate public service, but also accelerate public goods' supply efficiency through the cooperation of public and private sectors.
The application of the PPP mode in transportation infrastructure construction achieved more progress worldwide [610]. Researchers regard the PPP mode as an inexorable trend, for the reason of alleviating government's capital press and improving a project's construction schedule, as well as applying the limited funds into where it is needed [11,12].

At present, the main restriction factor for China highway development is the funds shortage $[10,13]$. Under the traditional investment and financing mode, the financial fund from governments constitutes the main part of capital source of a highway construction project. The limited funds from governments will directly lead to the fund shortage of the project and trigger financing risks [14-16]. To remedy this fund shortage issue, the State Council of the People's Republic of China promoted the PPP mode to reinforce local government's debt management in September 2014. In October 2015, the China's 13th Five-Year Plan for economic and social development also proposed to popularize the PPP mode. The applications of the PPP mode into highway construction projects in China can explicit each investor's duty and right, 
share responsibility of government's financial pressure, and make full use of private capital. The combination of the PPP financing mode and highway infrastructure construction projects in China has become an important tendency.

In March 2016, the Ministry of Finance of China and China's State Administration of Taxation published "the notice for implementation of replacing the business tax with a value-added tax pilot", and the highway planning and construction will also be affected by this new fiscal taxation policy. Meanwhile, in the application of PPP mode in highway projects, whether the government is responsible for land acquisition and resettlement (LAR) and changes in reasonable profit margins with different discount rates also affect the value of money assessment in China. Therefore, how to maximize the VFM value becomes the core content of the introducing PPP into highway infrastructure projects.

This paper discusses the highway infrastructure project's value of money assessment under PPP mode and mainly compares three scenarios, including the LAR, discount rates, and VAT pilot, to analyze the difference and then provides some suggestions for value of money assessment of highway projects under the PPP mode in China.

The contribution of this article lies in the following aspects. (1) This paper explores the VFM quantitative assessment of highway projects under PPP mode in China and discusses three reality questions in China, including whether the government is responsible for LAR, the discount rate changes, and the replacement of business tax by VAT. This paper is helpful for local government to negotiate with the social capital investors. (2) The real investment dilemma in highway projects under PPP mode has been lasting for a long time, while no academic research has provided the corresponding solutions to solve it. So this paper presents some suggestions for the PPP development of highway project, aiming at solving the local government's fund shortage and attracting more social capital's investment in highway projects.

The structure of this paper is as follows: Section 2 reviews the related literatures; Section 3 establishes the VFM assessment of highway project under PPP mode in China, Section 4 presents a case study of Heda freeway in Heilongjiang Province, then Section 5 includes the discussion and gives some suggestions for the PPP development of highway project, and Section 6 is the conclusion.

\section{Literature Review}

At present, the VFM mode of PPP has been widely used in the development of public programs and infrastructure projects in developed countries. For example, Scottish government [17] published Value for Money Assessment Guidance: Capital Programs and Projects; Federal Highway Administration [18] proposed Guidebook for Value for Money Assessment of America, which aimed to provide reference and guide for PPP projects. Take Chile as an example; during 1994 to 2006, this country adopted PPP mode in the construction of 36 highways and airport infrastructure programs; the total investment was more than 6 billion dollars [19].

In HM Treasury [4], VFM is defined as the optimum combination of whole-of-life costs and quality (or fitness for purpose) of the good or service to meet the user's requirement. The purpose of VFM assessment method is to realize the utilization efficiency optimization of public resource allocation and achieve the required quality at the lowest whole life cost. Public Sector Comparator (PSC) in the VFM is a key quantification tool to measure the VFM of a PPP project, and it represents the cost for procuring a project using the conventional delivery method, while the Shadow Bid provides the cost for a PPP delivery of the same reference project [18]. And then the investors choose the most efficient mode to build the infrastructure project.

In the theoretical field, the PPP mode application in highway projects also achieves more progress. Nakagawa and Hamajima [20] considered that a PPP project should be passed if this project can increase public benefits and tax revenues. Grimsey and Lewis [21] regarded the long-term loan rate as discount rates would be overconservative in PPP projects at UK, while a discount rate should fully consider the opportunity cost of financial funds and reflect the real value of these financial funds. Shaoul [22] thought a PPP project assessment should consider economic factors, social factors, and environmental factors. Zhang and Durango-Cohen [23] found that the tax burden of franchiser would be transferred to service providers, which can be solved by the alliance of public sectors and private investors.

Some scholars also queried the existing VFM assessment system and thought there were some inherent vices. Khadaroo [24] considered the presupposition assumptions as too subjective, which may increase the randomness of the VFM calculation and thus cannot exactly reflect the reality of the VFM's effect. Coulson [25] compared the invitation for bids of PFI in 2004 and 2006 and considered the financial model was too complex, which will easily make mistakes and is more dependent on the historical data. The risk of investment of transportation infrastructure needs to be considered [26]. Burke and Demirag [27] found that the traffic demand risk emanates within the operational phase, while the toll revenue calculation is conducted before the time when PPP becomes operational (at the planning stage). Otherwise, recently researchers focused more on the highway investment size, investment timing, and corresponding solutions [2830]; these studies can be helpful for the highway investment and avoid the invest risk.

In China, before the "Guide of Value for Money Assessment in PPP (Trail)" in December 2015, Gao et al. [6] and Ke et al. [31] discussed the necessity and possibility of establishing the VFM mode. According to the study of Chan et al. [32], the main impetus of adopting PPP in China is solving the government's financial tight budget and providing infrastructure and public services, but it will neglect the efficiency without assessing the VFM. In December 2015, the Ministry of Finance of China drew up "Guide of Value for Money Assessment in PPP (Trail)" [33], which provides principles and methods for the VFM qualitative assessment and quantitative assessment. In April 2015, the Ministry of Finance of China and the Ministry of Transport of China jointly published "the implementation opinions on the promoting PPP mode in toll highway field" [34], which had defined explicitly the basic principles, implementation requests, and supporting measures of toll highway PPP projects. In 2015, there were 
7 highway projects using PPP mode, while their total investment was 61.3 billion Yuan, which accounted for $7.3 \%$ of the total PPP projects in China [35].

From above analysis we can find that there are fewer studies paying attention to the effectiveness evaluation of highway projects under PPP mode in China. Therefore, this paper takes VFM assessment of highway projects under PPP mode as the study object and mainly focuses on three different scenarios, which include whether the government is responsible for LAR, the discount rate changes, and the replacement of the business tax by VAT pilot in highway PPP projects.

\section{Model Establishment for the VFM of Highway Project under PPP Mode in China}

3.1. Theoretical Framework. Presently, the Ministry of Transport of China has not published VFM of highway projects under PPP mode; we can only refer to "Guide of Value for Money Assessment in PPP (Trail)" from the Ministry of Finance of China. Just as PPP and VFM in other countries, the core of this guide is under the assumption that PPP mode and traditional government investment mode have the same output performance, by comparing the quantitative evaluation PPP value with the PSC value, determining whether the PPP mode can reduce the life cycle cost of a transport infrastructure project.

Calculating the PSC value based on VFM needs to set a reference project; here we present the definition of a reference project. According to the guideline from Ministry of Finance of China $[33,36]$, the reference project can be determined by supposing that a government adopts a realistic and most effective traditional investment embodiment, while a virtual project has the same outputs as a PPP project. According to the highway project assessment procedure under PPP mode, the quantitative evaluation process is shown in Figure 1.

3.2. VFM and PSC Relationship Analysis. The expense (cost) of highway project includes construction cost and operation cost; the revenue (benefit) includes toll revenue and revenues from service area and advertisements. Referring to the "project feasibility study report", we have compared the differences among all kinds of costs and revenues. The construction costs and operation costs as well as revenues from service area and advertisements quote relatively from "project feasibility study report". It is noted that the toll revenue is not an exact quote from "project feasibility study report", due to the financial evaluation in traditional construction projects, in which the toll revenue is also positive when calculated.

The difference between the PSC and the bidding price is the VFM of the potential project, as shown in Figure 2, from which we can find that only the cost of retained risk $(R r)$ is same in PSC and PPP modes. While for the pilot of replacing the business tax with a value-added tax, under a certain applicable tax rate, the main factors of a company's load tax are the proportion of the deductible operating costs, operation revenues, and operation costs.

To guarantee the accuracy of VFM quantitative assessment, the toll revenue needs to be proofread, which is the basis for calculating PPP and PSC values.
3.3. Toll Revenue. The toll revenues of a highway project under PPP mode and a reference project can be calculated by the following formula [37]:

$$
B_{1}, B_{1}{ }^{\prime}=\sum_{v=i}^{n}\left(T_{v}{ }^{\prime} \times T R_{v}{ }^{\prime} \times f_{v}{ }^{\prime} \times N_{v}{ }^{\prime} \times L\right)
$$

where $B_{1}, B_{1}{ }^{\prime}$ are toll revenues of a highway PPP project and a reference project, respectively (Yuan); $T_{v}^{\prime}$ is the average daily traffic volume of vehicle type $v$ (vehicle per day); $f_{v}^{\prime}$ is the proportional effective toll of vehicle type $v ; T R_{v}{ }^{\prime}$ is the toll standard of vehicle type $v$ (Yuan per vehicle per kilometer); $N_{v}{ }^{\prime}$ are the effective charging days of vehicle type $v$ (day); $L$ is the length of the highway project (kilometers).

The relationship among these parameters can be expressed in Table 1.

3.4. PSC Value Calculation. The PSC value calculation includes calculating the raw $P S C_{0}$, the competitive neutrality $C N V_{a}$, the cost of transferable risk $R_{t}$, and the cost of retained risk $R_{r}$ (as shown in Figure 2), as shown in the following formula:

$$
P S C=P S C_{0}+C N V_{a}+R_{t}+R_{r}
$$

where PSC is Public Sector Comparator value (Yuan); $P S C_{0}$ is the raw value of PSC (Yuan); $C N V_{a}$ is competitive neutrality adjustment value (Yuan); $R_{t}$ is cost of transferable risks; $R_{r}$ is cost of retained risk; this value can be equally deducted in PPP value calculation, so it is not calculated.

In formula (2), the raw $P S C_{0}$ can be calculated by the following expression:

$$
P S C_{0}=\left(C_{1}-G\right)+\left(C_{2}-B\right)+C_{x}
$$

where $C_{1}$ are construction costs of the reference project (Yuan); $G$ are capitalization revenues of the reference project, which should be subtracted from construct costs (Yuan); $C_{2}$ are operating and maintenance costs of the reference project (Yuan); $B$ are third-party revenues, including the toll revenues $B=B_{1}+B_{2}$ and revenues from the service area and advertisements (Yuan); $C_{x}$ are other costs of the reference project, including construction cost, consulting service fees, construction costs of connected facilities, and supporting projects of the reference project, as well as the third-party revenues for providing surrounding land or business development remuneration (Yuan).

Competitive neutrality adjustment value $C N V_{a}$ aims to eliminate a public sector's competitive edge compared to a private investor under the reference project. The public sector's competitive edge includes the spending on land cost, government reviews and approvals cost and income tax.

The cost of risk $R_{i}$ includes the cost of transferable risk $R_{t}$ and the cost of retained risk $R_{r}$. Quantitative method of calculating cost of risks includes probability method, ratio method, and Monte Carlo method, and this paper uses probability method. Through setting five different scenarios, including 


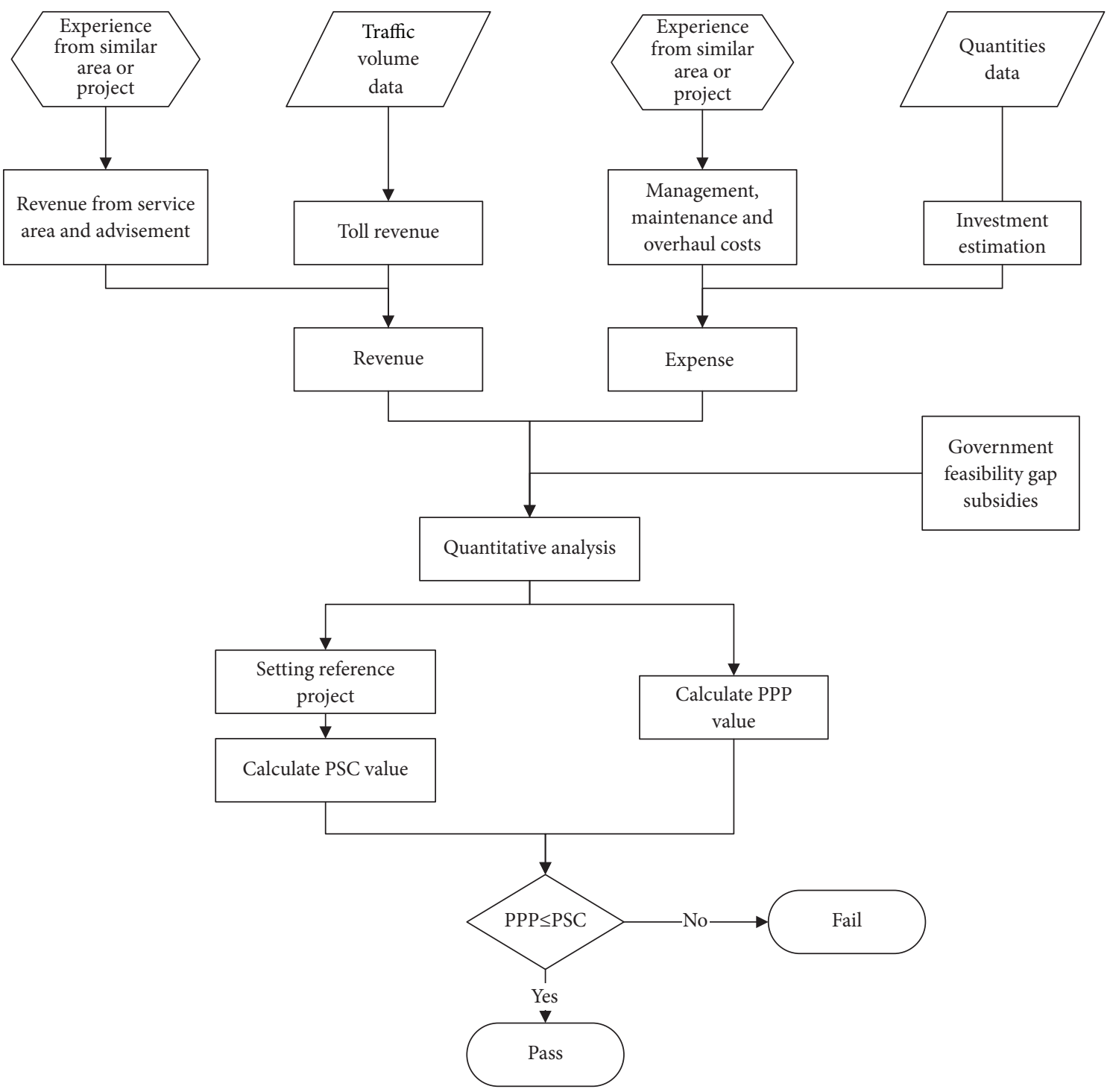

FIgURE 1: The quantitative evaluation process of a highway project under the PPP mode.

TABLE 1: Toll revenue calculation parameters relationship.

\begin{tabular}{lcccc}
\hline Parameters & $\begin{array}{c}\text { Project feasibility } \\
\text { study report }\end{array}$ & Reference PSC project & PPP project & Reason \\
\hline $\begin{array}{l}\text { The average daily traffic volume of vehicle } \\
\text { type } v\end{array}$ & $T_{v}{ }^{0}$ & $T_{v} \leq T_{v}{ }^{0}$ & $T_{v}{ }^{\prime} \leq T_{v}{ }^{0}$ & $\begin{array}{c}\text { Traffic volume } \\
\text { forecasting more } \\
\text { optimistic }\end{array}$ \\
The effective toll proportion of vehicle type $v$ & $f_{v}{ }^{0}$ & $f_{v} \leq T_{v}{ }^{0}$ & $f_{v}{ }^{\prime} \leq f_{v}{ }^{0}$ & $T_{v}$ \\
The toll standard of vehicle type $v$ & $T R_{v}{ }^{0}$ & $T R_{v}=T R_{v}{ }^{0}=T R_{v}{ }^{0}$ & $N_{v}{ }^{\prime} \leq N_{v}{ }^{0}$ & No change 1 \\
The length of the highway project & $N_{v}{ }^{0}$ & $N_{v} \leq N_{v}{ }^{0}$ & See note 2 \\
\hline
\end{tabular}

Note 1: consider the existence of special vehicles such as the military vehicles performing official duties, police cars, fire engines, and freight trucks delivering fresh agricultural projects without having to pay highway tolls.

Note 2: during Spring Festival, the Qingming Festival, the Holiday of Labors Day, and the National Day, for a total of 20 days, the passenger cars (seats less than 7), toll fee is waived; other vehicle types are the same as that in the project feasibility study report. 


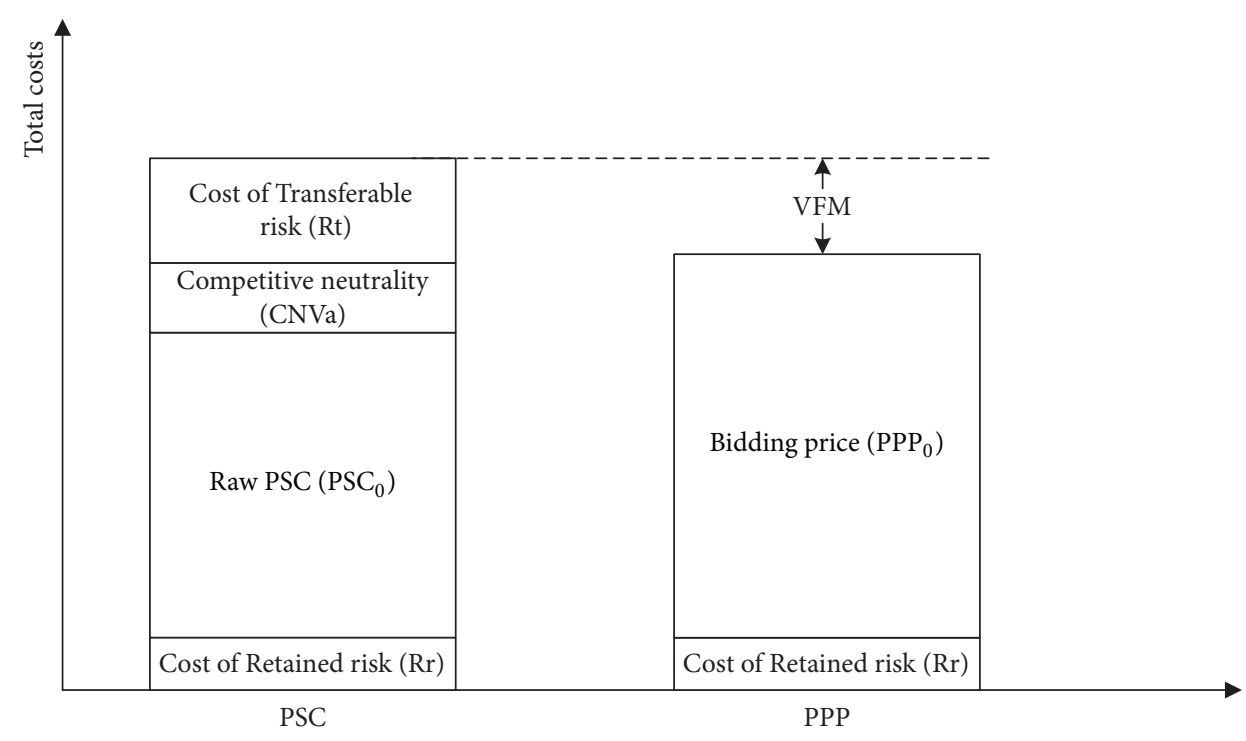

Figure 2: Assessing the VFM and PSC.

the good, basic, bad, worse, worst scenario, and then calculating the weighted cost of risks by reckoning the probability, the calculation formula is as follows.

$$
R_{i}=\sum_{j}\left(R_{i j} \times q_{j}\right)
$$

where $R_{i}$ is the cost of risk $R_{i}$, including the cost of transferable risk $R_{t}$ and the cost of retained risk $R_{r} ; R_{i j}$ is the risk consequence value when the $j$ scenario happens; $q_{j}$ is the probability when the $j$ scenario happens; the cost of transferable risk $R_{t}$ can make up 70\%-85\% in the total cost of risk $R_{i}$.

3.5. PPP Calculation. The PPP value equals the public sector's bidding price $P P P_{0}$ plus the cost of retained risk $R_{r}$, which can be expressed as

$$
P P P=P P P_{0}+R_{r}
$$

where $P P P_{0}$ is the bidding price (Yuan).

The public sector's bidding price $P P P_{0}$ includes construction costs, operating and maintenance costs, and other costs.

$$
P P P_{0}=\left(C_{1}{ }^{\prime}-G^{\prime}\right)+\left(C_{2}^{\prime}-B^{\prime}\right)+C_{x}{ }^{\prime}
$$

where $C_{1}{ }^{\prime}$ are construction costs of the PPP mode (Yuan); $G^{\prime}$ are capitalization revenues of the PPP mode project, which should be subtracted from construct costs (Yuan); $C_{2}{ }^{\prime}$ are operating and maintenance costs of the PPP mode (Yuan); $B^{\prime}$ indicates $B=B_{1}^{\prime}+B_{2}^{\prime}$ including toll revenues $B_{1}^{\prime}$ and the service area and advertisement revenues $B_{2}{ }^{\prime}$ (Yuan); $C_{x}{ }^{\prime}$ denotes other costs of the PPP mode, including the consulting service fees, market testing fee, transfer the compensation, project's connected facilities and supporting project's construction costs, the revenues for providing surrounding land or business development remuneration, and loan interest rate (Yuan); $R_{r}$ is cost of retained risk; this value can be equally deducted in PSC value calculation, so it is not calculated.
3.6. VFM Assessment. The VFM calculation can be expressed as follows:

$$
\begin{aligned}
& V F M=P S C-P P P \\
& f_{V F M}=(P S C-P P P) \div P S C \times 100 \%
\end{aligned}
$$

where VFM is the value of VFM; $f_{V F M}$ is the index of VFM.

If $V F M>0, f_{V F M}>0$, which means that the PPP mode project passes the quantitative assessment, this PPP project is profitable. Otherwise, the PPP mode project fails in the quantitative assessment.

3.7. Replacing the Business Tax with a VAT Pilot. In March 2016, China's Ministry of Finance and China's State Administration of Taxation have jointly published "the notice for implementation of replacing the business tax with a value-added tax pilot". In the study of Zheng and Zhu [38], the highway planning and construction will be affected by the replacing the business tax with a VAT pilot policy.

Before the pilot that replaces the business tax with a valueadded tax, $3.3 \%$ of highway toll revenues should pay the tax payable and attached; after this pilot, the applicable tax rate is $11 \%$, and the rate with deduction of VAT is $17 \%$. Therefore, this pilot can affect the highway project on the tax, which is shown in Table 2.

Here we assume the gross profit margin of a highway PPP project company is $m$; then we get $m=\left(B-C_{2}\right) / B$. According to Table 2, we can simplify the calculation formula of changes in load tax as

$$
\begin{aligned}
p(k, m) & =\frac{0.145 k * C_{2}-0.066 B}{0.033 B} \\
& =4.4 k *(1-m)-2.0
\end{aligned}
$$

where $p$ denotes load tax rate changes of a project company after the replacing the business tax with a value-added tax 
TABLE 2: The influence of replacing the business tax by a value-added tax pilot on highway projects.

\begin{tabular}{lcc}
\hline Tax type & Items & Calculation \\
\hline & Operating revenue & $\mathrm{B}$ \\
Collect business tax & Operating cost & $\mathrm{C}_{2}$ \\
& Operating profit & $\mathrm{B}-\mathrm{C}_{2}$ \\
& The tax payable and attached & $\mathrm{B} * 3.3 \%$ \\
\hline & Operating revenue does not include tax & $\mathrm{B} /(1+11 \%)$ \\
Collect value-added tax & Substituted money on VAT (See note 3$)$ & $\mathrm{B} * 11 \% /(1+11 \%)$ \\
& No tax deductible operating costs & $\mathrm{k} * \mathrm{C}_{2} /(1+17 \%)$ \\
& Input VAT ( input value added tax ) & $\mathrm{k} * \mathrm{C}_{2} * 17 \% /(1+17 \%)$ \\
\hline Operation company's tax change & The VAT payable - The tax payable and attached & $\mathrm{B} * 11 \% /(1+11 \%)-\mathrm{k} * \mathrm{C}_{2} * 17 \% /(1+17 \%)-\mathrm{B} * 3.3 \%$ \\
\hline Note 3: for the reason of highway construction costs in project investment estimation, here only the operating cost's VAT deduction is considered.
\end{tabular}

TABLE 3: The toll revenue of proposed project, unit: million Yuan.

\begin{tabular}{lccccccc}
\hline Category & 2015 & 2019 & 2023 & 2028 & 2033 & 2038 & 2048 \\
\hline$\langle$ Feasibility Study Report $\rangle$ & 32.47 & 47.34 & 68.12 & 97.00 & 135.92 & 169.15 & 210.49 \\
\hline PPP projects & 25.98 & 37.87 & 54.50 & 77.60 & 108.74 & 135.32 & 168.39 \\
\hline
\end{tabular}

pilot (\%); $k$ is deductible proportion of operating costs (\%); $m$ is gross profit margin of a project company (\%).

From above formula we can see that a highway PPP project company's load tax rate change $p$ is connected with the deductible proportion of operating costs $k$ and gross profit margin $m$. Figure 3 reveals the relationship among $p$ (as the dependent variable), $k$, and $m$ (as an independent variable).

\section{Case study of Heda Freeway in Heilongjiang Province, China}

4.1. Basic Data of the Heda Freeway Project. The proposed project Jiamusi transit section of Heda freeway is located in the northern Heilongjiang Province, and its total length is $25.837 \mathrm{~km}$, and the design speed is $100 \mathrm{~km} / \mathrm{h}$, with roadbed width of $26.0 \mathrm{~m}$ for four-lane highway. The total project cost is 2096.43 million Yuan.

The project adopts the PPP mode, with the government sector and the private sector providing $28 \%$ and $29 \%$ of total funds, respectively. The total $57 \%$ of funds as the capital can be used to establish the project company. The remaining funds and construction period interest will be invested by the project company; the project combines the "User Pays Feasibility" with "Subsidy Gap", and the government does not participate in revenue sharing. The toll revenue in project feasibility study report and the toll revenue after being reviewed were shown in Table 3.

Parameters setting is as follows: lending rates $=4.90 \%$ (Bank of China announced on October 24, 2015); discount rate $=4.0 \%$ (according to Heilongjiang Province local government long-term bonds of 3.63\%, determined comprehensively); reasonable profit $=5.90 \%$ (increase $1 \%$ on the basis of long-term lending rates).

\subsection{VFM Evaluation}

\subsubsection{PSC Value Calculation}

(1) Calculation of $P S C_{0}$. After calculating, construction costs of the reference project $C_{1}$ are shown in Table 4. Capital gains theoretically should be the recyclable residual value of fixed assets at the end of the operation period, which highway projects may not consider, $R=0$. Costs for the operating period $C_{2}$ and the third-party income $B=B_{1}^{\prime}+B_{2}$ are also shown in Table 4 , where $B_{1}^{\prime}$ is the toll revenue, and $B_{2}$ is the service area and facilities along income. Additional costs for this project do not exist, $C_{x}=0$. After calculating, the raw $P C_{0}=1108.74$ million Yuan.

(2) Calculation of $\mathrm{CNV}_{a}$. In the listed project competitive neutrality adjustment values, the reference project is also required to pay water conservancy project funds. The rest of listed adjustment values are equivalent expenditure that both government and social capital require. Therefore, adjustment values include income tax, water conservancy funds, and VAT. Thus, for the reference project, the water conservancy fund for the government to pay is 38.07 million Yuan; social capital contributed VAT is 82.11 million Yuan; income tax is 99.96 million Yuan. Then we can get the value of $C N V_{a}=144$ million Yuan.

(3) Calculation of $R_{t}$. Highway PPP projects often use probabilistic methods to determine the risk costs. Risks that can be transferred in highway PPP projects mainly include the estimated investment risks and financial risks. Probabilistic methods scenarios for determining risk costs are shown in Tables 5 and 6, respectively. 
TABLE 4: The calculation process of $P S C_{0}$ value, unit: million Yuan.

\begin{tabular}{lccccccccccc}
\hline project & \multicolumn{3}{c}{ Construction period } & \multicolumn{5}{c}{ operation period } \\
\hline Features & 2016 & 2017 & 2018 & 2019 & 2023 & 2028 & 2033 & 2038 & 2043 & 2048 \\
\hline 1 Cash inflow & 0 & 0 & 0 & 110.21 & 110.90 & 111.84 & 113.03 & 114.50 & 115.87 & 117.48 \\
\hline 1.1 Operating Income & 0 & 0 & 0 & 28.18 & 40.97 & 58.84 & 83.68 & 117.15 & 145.72 & 181.28 \\
\hline 1.2 Recycling residual value & 0 & 0 & 0 & 0 & 0 & 0 & 0 & 0 & 0 & 0 \\
\hline 1.3 Financial subsidy & 0 & 0 & 0 & 82.03 & 69.93 & 53.00 & 29.35 & -2.65 & -29.85 & -63.79 \\
\hline 2 Cash outflow & 187.19 & 272.32 & 241.35 & 110.21 & 110.90 & 111.84 & 113.03 & 114.50 & 115.87 & 117.48 \\
\hline 2.1 Capital investment & 176.1 & 234.8 & 176.1 & 0 & 0 & 0 & 0 & 0 & 0 \\
\hline 2.2 Operations Management Fee & 0 & 0 & 0 & 2.23 & 2.37 & 2.55 & 2.75 & 2.96 & 3.19 & 3.43 \\
\hline 2.3 Maintenance costs & 0 & 0 & 0 & 2.74 & 2.91 & 3.13 & 3.37 & 3.63 & 3.91 & 4.22 \\
\hline 2.4 Overhaul costs & 0 & 0 & 0 & 0 & 0 & 0 & 0 & 0 & 0 \\
\hline 2.5 Water conservancy fund & 0 & 0 & 0 & 0.85 & 1.23 & 1.77 & 2.51 & 3.51 & 4.37 & 5.44 \\
\hline 2.6 Debt service & 11.09 & 37.52 & 65.25 & 104.40 & 104.40 & 104.40 & 104.40 & 104.40 & 104.40 & 104.40 \\
\hline 3 Net cash flow(1-2) & -187.19 & -272.32 & -241.35 & 0 & 0 & 0 & 0 & 0 & 0 \\
\hline
\end{tabular}

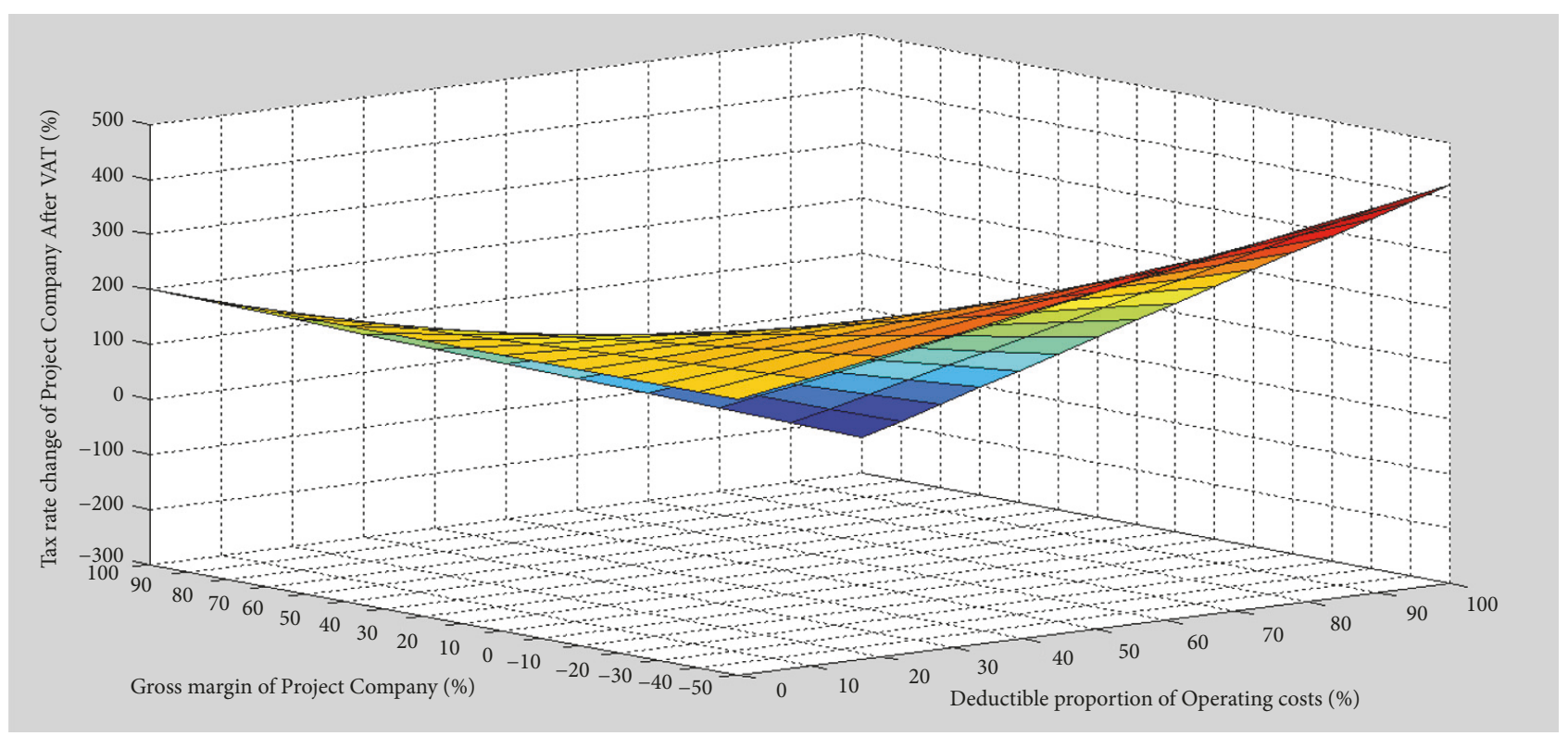

FIgURE 3: The relationship among $p, k$, and $m$.

Here we assumed that the transfer risk takes $70 \%$. According to estimation, the cost of risks that can be transferred $\left(R_{t}\right)$ is 197.25 million Yuan.

(4) Calculation of PSC. In summary, PSC $=P C_{0}+C N V_{a}+R_{t}$ $=1108.74+144.00+197.25=1449.99$ million Yuan.

4.2.2. PPP Value Calculation. Because the cost of risk retention can bear the cost inside of risk retention, we only calculate construction costs and operating costs that a shadow government offers.

According to the analysis of $P S C$ values and $P P P_{0}$ values, the project life cycles of $P S C$ and $P P P$ values are calculated (see in Table 7); Table 8 shows specific results for the baseline scenario. The project $V F M=241.85$ million Yuan and
$f_{V F M}=16.7 \%$, both of which are positive, which indicate that the project is suitable for the PPP mode.

\section{Discussion of Different Scenarios}

Based on domestic actual situation and international experiences, it is difficult to form a mature and sophisticated discussion due to lack of sufficient practice and data accumulation. Meanwhile, VFM quantitative assessment is also at the stage of exploration, and there are several uncertain factors which may affect the VFM. This paper compares three scenarios, including the LAR, discount rate change, and VAT pilot to analyze the differences and then provides some suggestions for value of money assessment of highway projects under PPP mode in China. 
TABLE 5: The estimated investment risks scenario of probabilistic methods, unit: million Yuan.

\begin{tabular}{lccc}
\hline Scenario & Risk consequences & Probability & Weighted \\
\hline favorable & More than 5\% construction cost savings & $5 \%$ & -5.24 \\
Basic & Construction cost savings 5\% - cost overruns 5\% & $10 \%$ & 0 \\
Unfavorable & Construction cost overruns 5\% -15\% & $50 \%$ & 104.82 \\
Poor & Construction cost overruns 15\% -25\% & $25 \%$ & 91.72 \\
Worst & More than 25\% of construction cost overruns & $10 \%$ & 52.41 \\
& Weighted average & & 243.71 \\
\hline
\end{tabular}

TABLE 6: The financial risks scenario of probabilistic methods, unit: million Yuan.

\begin{tabular}{lccc}
\hline scenario & Risk consequences & Probability & Weighted \\
\hline favorable & More than 20\% higher than the estimated value & $20 \%$ & -5076 \\
Basic & As same as estimated value & $40 \%$ & 0 \\
Unfavorable & $10 \%$ lower than the estimated value & $20 \%$ & 2538 \\
Poor & $20 \%$ lower than the estimated value & $10 \%$ & 2538 \\
Worst & More than 30\% lower than the estimated value & $10 \%$ & 3807 \\
& Weighted average & 3807 \\
\hline
\end{tabular}

TABLE 7: The calculation process of $P P P_{0}$, unit: million Yuan.

\begin{tabular}{lcccccccccc}
\hline Project & \multicolumn{3}{c}{ Construction period } & \multicolumn{5}{c}{ Operation period } \\
\hline Features & 2016 & 2017 & 2018 & 2019 & 2023 & 2028 & 2033 & 2038 & 2043 & 2048 \\
\hline 1 Cash inflow & 0 & 0 & 0 & 71.74 & 84.47 & 102.36 & 127.21 & 160.71 & 189.30 & 224.88 \\
\hline 1.1 Operating Income & 0 & 0 & 0 & 28.18 & 40.97 & 58.84 & 83.68 & 117.15 & 145.72 & 181.28 \\
\hline 1.2 Recycling residual value & 0 & 0 & 0 & 0 & 0 & 0 & 0 & 0 & 0 & 0 \\
\hline 1.3 Financial subsidy & 0 & 0 & 0 & 43.27 & 43.27 & 43.27 & 43.27 & 43.27 & 43.27 & 43.27 \\
\hline 1.4 Input VAT & 0 & 0 & 0 & 29 & 23 & 25 & 27 & 29 & 31 \\
\hline 2 Cash outflow & 189.89 & 266.72 & 222.13 & 69.90 & 70.16 & 72.23 & 75.02 & 78.69 & 111.29 & 129.60 \\
\hline 2.1 Owning funds & 183.29 & 244.38 & 183.29 & 0 & 0 & 0 & 0 & 0 & 0 \\
\hline 2.2 Operations Management Fee & 0 & 0 & 0 & 2.23 & 1.77 & 1.91 & 2.06 & 2.22 & 2.39 & 2.57 \\
\hline 2.3 Maintenance costs & 0 & 0 & 0 & 2.74 & 2.18 & 2.35 & 2.53 & 2.73 & 2.94 & 3.16 \\
\hline 2.4 Overhaul costs & 0 & 0 & 0 & 0 & 0 & 0 & 0 & 0 & 0 \\
\hline 2.5 Output VAT & 0 & 0 & 0 & 2.79 & 4.06 & 5.83 & 8.29 & 11.61 & 14.44 & 17.96 \\
\hline 2.6 Income tax & 0 & 0 & 0 & 0 & 0 & 0 & 0 & 0 & 22.60 & 33.66 \\
\hline 2.7 Provident Fund & 0 & 0 & 0 & 0 & 0 & 0 & 0 & 0 & 6.78 & 10.10 \\
\hline 2.8 Debt service & 6.60 & 22.34 & 38.84 & 6214 & 62.14 & 62.14 & 62.14 & 62.14 & 62.14 & 62.14 \\
\hline 3 Net cash flow(1-2) & -189.89 & -266.72 & -222.13 & 1.84 & 14.31 & 30.13 & 52.19 & 82.02 & 78.02 & 95.28 \\
\hline
\end{tabular}

TABLE 8: VFM comparison under different scenarios, unit: million Yuan.

\begin{tabular}{lccccc}
\hline Scenarios & $\begin{array}{c}\text { Construction of } \\
\text { expenditure }\end{array}$ & $\begin{array}{c}\text { Operating } \\
\text { subsidies per year }\end{array}$ & $P S C$ & $P P P$ & $f_{V F M}$ \\
\hline $\begin{array}{l}\text { Baseline scenario } \\
\text { Scenario 1: Local } \\
\text { governments are }\end{array}$ & 587.00 & 43.27 & 1449.99 & 1208.14 & 241.85 \\
$\begin{array}{l}\text { responsible for } \\
\text { LAR }\end{array}$ & 609.07 & 41.82 & 1446.38 & 1206.26 & 240.12 \\
$\begin{array}{l}\text { Scenario 2: } \\
\text { discount rate 6\% }\end{array}$ & 587.00 & 60.05 & 1323.43 & 1216.97 & 106.46 \\
$\begin{array}{l}\text { Scenario 3: } \\
\text { Business tax and } \\
\text { surcharges }\end{array}$ & 587.00 & 39.43 & 1391.03 & 1149.11 & 241.91 \\
\hline
\end{tabular}


5.1. Under the Scenario of LAR. LAR is not only the key but also a difficult part of highway construction projects. Usually, it is most likely to be an origin of social risks. This is because local governments are familiar with local area projects so that they are more suitable for LAR. It would be easier for governments to attract social capital and reduce projects' risks if governments shoulder the responsibility of LAR. Here the proposed project $\mathrm{LAR}=20.07$ million Yuan.

It can be seen from Table 8 that there will be an extra expenditure of 22.07 million Yuan during construction when the local government is responsible for LAR compared with the case where they ignore LAR. However, operating subsidy reduces by 1.45 million Yuan per year for the latter case, and $V F M$ and $f_{V F M}$ do not change significantly. Given that governments' bearing responsibility for LAR has a great temptation for social capital, it is recommended that governments are responsible for LAR if conditions permit.

5.2. Under the Scenario of the Discount Rate Changes. Not only the profit level of social capital but also the government's annual subsidy is directly related to the discount rate. Taking the case of a $4 \%$ discount rate as the baseline, the other parameters are unchanged, compared with the scenario of domestic usual discount rate of $6 \%$.

As we can see from Table 8, compared with a $4 \%$ discount rate, at the time of $6 \%$ discount rate, government expenditure during construction period is unchanged while operating subsidy increases by 16.78 million Yuan per year, and VFM and $f_{V F M}$ decreased remarkably. Therefore, a lower discount rate is favorable for governments, and governments need to minimize the discount rate within a reasonable range when they are in negotiations with the social capital investors.

5.3. Under the Scenario of Replacing Business Tax with ValueAdded Tax (VAT). The gross profit of a highway PPP project is always low or even negative (about 20\%) and the deductible proportion of operating costs is also low (about $40 \%$ ), according to Zheng and Zhu [38]. The replacement of business tax by VAT evidently affects highway PPP projects, and it usually leads to a $65 \%$ increase in the tax burden.

From Table 8, we can compare the pay VAT. To pay the business tax, the government expenditure during construction period is constant; while operating expenses decrease by 3.84 million Yuan per year, VFM and $f_{V F M}$ increase slightly, which implies that replacing the business tax with VAT is adverse for highway PPP projects, which is shown earlier in Figure 1, describing that replacing the business tax with VAT is negative for overall burden of highway PPP project, and will increase government subsidies.

From the above analysis, here we can obtain the related management insights into the PPP development of freeway projects. Firstly, local government should be responsible for LAR if condition permits, which will attract social capital's investment on highway projects. Second, under a reasonable lower discount rate, local government can save some expenditure and the social capital investors may invest more actively. At last, the replacement of business tax by VAT will increase the highway project company's burden, so local government may provide more subsidies to make up the loss for the highway project.

In addition, this manuscript only considered the tax the investor paid in the project cost in the model (see in Section 3.7); the change of tax rate should also be taken into account in the PPP agreement and be borne by the government via toll/subsidy adjustment mechanism, which will be the focus of our future research.

\section{Conclusions}

This paper focused on the three actual development demands of highway project' value of money assessment under PPP mode in China, including whether the government is responsible for land acquisition and resettlement (LAR), the discount rate changes, and the policy replacing business tax by value-added tax in 2016. This paper discussed Value for Money (VFM) quantitative assessment of highway projects under PPP mode in China, which considers currently three actual development demands in China. A case study of Heda freeway has been presented, whose results show that a higher discount rate is profitable for the private sector, while a lower discount rate is favorable for the government sector. Meanwhile, this paper attempted to analyze the influence of replacing business tax by a VAT pilot. For a lower gross profit margin and deductible proportion of operating costs, the load tax rate of highway PPP project companies will increase.

This paper did not consider weather risks on highway PPP projects, especially for Heilongjiang Province's current reality that the crossing traffic volume is lower in the remote location of Northeast China (such as Heilongjiang Province, Inner Mongolia Autonomous Region) in winter than in southeast of China (such as Guangdong, Zhejiang Province). In the future, combining more highway traffic volume data, we will explore the effect of the traffic volume on highway PPP projects.

\section{Data Availability}

The data used to support the findings of this study are available from the corresponding author upon request.

\section{Conflicts of Interest}

The authors declare no conflicts of interest.

\section{Acknowledgments}

This research was supported by the National Natural Science Foundation of China (71603063), Natural Science Foundation of Heilongjiang (no. E2016032), China Postdoctoral Science Foundation funded project (no. 2013M540299), and the Fundamental Research Funds for the Central Universities (no. HIT.NSRIF.2015075).

\section{References}

[1] J. Fox and N. Tott, The PFI Handbook, Jordan Publishing Limited, Bristol, 1999. 
[2] M. Spackman, "Public-private partnership: Lessons from the British approach," Economic Systems, vol. 26, no. 3, pp. 283-301, 2002.

[3] HM Treasury. (2004): Value for Money Assessment Guidance. https://www.bipsolutions.com/docstore/pdf/8038.pdf.

[4] HM Treasury. (2006): Value for Money Assessment Guidance. http://webarchive.nationalarchives.gov.uk/20130129110402/http:// www.hm-treasury.gov.uk/d/vfm_assessmentguidance061006opt .pdf.

[5] HM Treasury. (2012): A New Approach to Public-Private Partnerships. https:/www.gov.uk/government/uploads/system/uploads/ attachment_data/file/205112/pf2_infrastructure_new_approach_ to_public_private_parnerships_051212.pdf.

[6] H. Gao, Y. Liu, X. Qi, and H. Fu, "Research on VFM assessment method based on PPP mode international practice: take England Germany and Singapore as example," Project Management Technology, vol. 9, no. 3, pp. 18-21, 2011.

[7] P. Barrett, "Commentary: Performance Audit of PPPs - Getting the Basics Right," Australian Accounting Review, vol. 21, no. 1, pp. 99-106, 2011.

[8] H. Iseki and R. Houtman, "Evaluation of progress in contractual terms: Two case studies of recent DBFO PPP projects in North America," Research in Transportation Economics, vol. 36, no. 1, pp. 73-84, 2012.

[9] R. R. Geddes and B. L. Wagner, "Why do U.S. states adopt public-private partnership enabling legislation?" Journal of Urban Economics, vol. 78, pp. 30-41, 2013.

[10] M. Xu, S. Grant-Muller, and Z. Gao, "Evolution and assessment of economic regulatory policies for expressway infrastructure in China," Transport Policy, vol. 41, pp. 42-49, 2015.

[11] D. Hall and R. Davis, "Terminology of public-private partnerships," Public Services International Research Unit (PSIRU), vol. 7, pp. 78-82, 2003.

[12] M. Percoco, "Quality of institutions and private participation in transport infrastructure investment: Evidence from developing countries," Transportation Research Part A: Policy and Practice, vol. 70, pp. 50-58, 2014.

[13] R. Mu, M. D. Jong, and J. Koppenjan, "The rise and fall of PublicPrivate Partnerships in China: a path-dependent approach," Journal of Transport Geography, vol. 19, no. 4, pp. 794-806, 2011.

[14] Y. L. Xu, J. F. Y. Yeung, A. P. C. Chan, D. W. M. Chan, S. Q. Wang, and Y. Ke, "Developing a risk assessment model for PPP projects in China-a fuzzy synthetic evaluation approach," Automation in Construction, vol. 19, no. 7, pp. 929-943, 2010.

[15] Y. Guo, Study of risk allocation and income distribution in highway Public-Private Partnership project, A dissertation of Changan university [dissertation, thesis], 2013.

[16] Z. Cheng, Y. Ke, J. Lin, Z. Yang, and J. Cai, "Spatio-temporal dynamics of public private partnership projects in China," International Journal of Project Management, vol. 34, no. 7, pp. 12421251, 2016.

[17] Scottish Government. (2011): Value for Money Assessment Guidance: Capital Programmes and Projects. http://www.scottishfuturestrust.org.uk/files/publications/Value_for_Money_Assessment_Guidance_-_Capital_Programmes_and_Projects_(October_ 2011).pdf.

[18] Federal Highway Administration. (2013): Guidebook for Value for Money Assessment. http://www.fhwa.dot.gov/ipd/pdfs/p3/ p3_guidebook_vfm_1213.pdf.

[19] PPP Forum. (2006. Annual Review 2006. http://www.ppp forum.com.
[20] Y. Nakagawa and H. Hamajima, "A Study the Estimation of VFM of PFI for Local Road Project in Japan," in Proceedings of the Proceedings- Japan Society of Civil Engineers, pp. 195-200, 2002.

[21] D. Grimsey and M. K. Lewis, "Are Public Private Partnerships value for money?: Evaluating alternative approaches and comparing academic and practitioner views," Accounting Forum, vol. 29, no. 4, pp. 345-378, 2005.

[22] J. Shaoul, "A critical financial analysis of the Private Finance Initiative: Selecting a financing method or allocating economic wealth," Critical Perspectives on Accounting, vol. 16, no. 4, pp. 441-471, 2005.

[23] Z. A. Zhang and P. L. Durango-Cohen, "A strategic model of public-private partnerships in transportation: effect of taxes and cost structure on investment viability," Research in Transportation Economics, vol. 36, no. 1, pp. 9-18, 2012.

[24] I. Khadaroo, "The actual evaluation of school PFI bids for value for money in the UK public sector," Critical Perspectives on Accounting, vol. 19, no. 8, pp. 1321-1345, 2008.

[25] A. Coulson, "Value for money in pfi proposals: A commentary on the UK treasury guidelines for public sector comparators," Public Administration, vol. 86, no. 2, pp. 483-498, 2008.

[26] D. Z. Zhang, F. Z. Zou, S. Y. Li, and L. Y. Zhou, "Green Supply Chain Network Design with Economies of Scale and Environmental Concerns," Journal of Advanced Transportation, vol. 14, pp. 10-1155, 2017.

[27] R. Burke and I. Demirag, "Changing perceptions on PPP games: Demand risk in Irish roads," Critical Perspectives on Accounting, vol. 27, pp. 189-208, 2015.

[28] Z.-C. Li, Q.-W. Guo, W. H. K. Lam, and S. C. Wong, “Transit technology investment and selection under urban population volatility: A real option perspective," Transportation Research Part B: Methodological, vol. 78, pp. 318-340, 2015.

[29] S. Li and H. Cai, "Government incentive impacts on private investment behaviors under demand uncertainty," Transportation Research Part E: Logistics and Transportation Review, vol. 101, pp. 115-129, 2017.

[30] D. Zhang, Q. Zhan, Y. Chen, and S. Li, "Joint optimization of logistics infrastructure investments and subsidies in a regional logistics network with CO2 emission reduction targets," Transportation Research Part D: Transport and Environment, vol. 60, pp. 174-190, 2018.

[31] Y. Ke, X. Liu, and S. Wang, "Equitable Financial Evaluation Method for Public-Private Partnership Projects," Tsinghua Science and Technology, vol. 13, no. 5, pp. 702-707, 2008.

[32] A. P. C. Chan, P. T. I. Lam, D. W. M. Chan, E. Cheung, and Y. Ke, "Drivers for adopting public private partnerships-empirical comparison between China and Hong Kong special administrative region," Journal of Construction Engineering and Management, vol. 135, no. 11, pp. 1115-1124, 2009.

[33] Ministry of Finance of China. (2015): Guide of Value for Money Assessment in PPP (Trail). (in Chinese) http://jrs.mof.gov.cn/ zhengwuxinxi/zhengcefabu/201512/t20151228_1634669.html.

[34] Ministry of Finance of China, Ministry of Transport of China. (2015): The implementation opinions on the promoting PPP mode in toll highway field. (in Chinese) http://jjs.mof.gov.cn/ zhengwuxinxi/tongzhigonggao/201505/t20150506_1227769.html.

[35] Ministry of Finance of China. (2016). Government and social capital cooperation center [EB/OL]. (2016-03-04). http://www .cpppc.org/. 
[36] Ministry of Finance of China, China's State Administration of Taxation. (2016): The notice for implementation of replacing the business tax with a value-added tax pilot. (in Chinese) http:// www.chinatax.gov.cn/n810341/n810755/c2043931/content.html.

[37] Ministry of Housing and Urban-Rural Development of China, Ministry of Transport of China. (2010): Highway Construction Project Economic Evaluation method and parameters. Beijing: China Planning Press.

[38] J. Zheng and H. Zhu, Comment: Impact analysis of the replacing the business tax with a value-added tax pilot on transportation industry company, China Credit Rating CO., Ltd., 2012. 


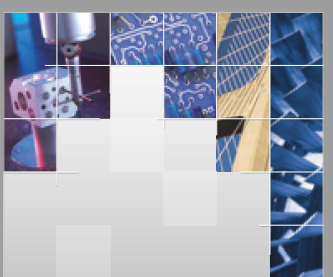

\section{Enfincering}
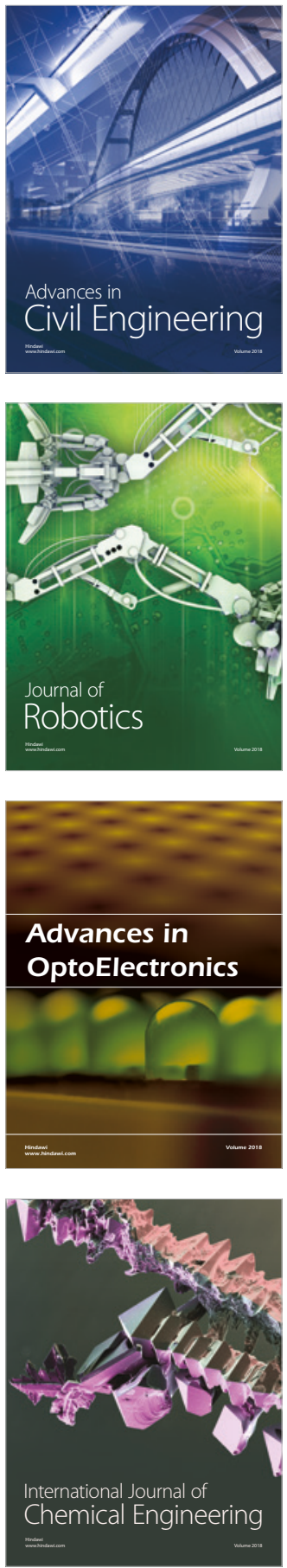

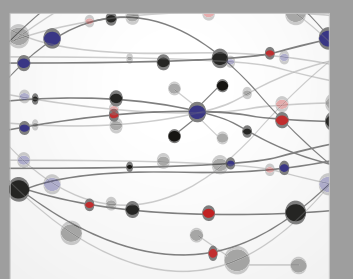

\section{Rotating \\ Machinery}

The Scientific World Journal

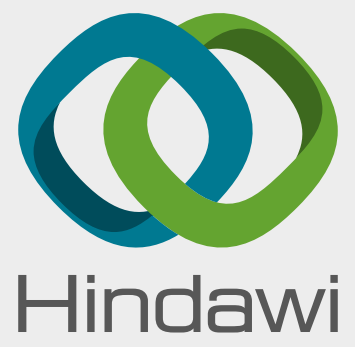

Submit your manuscripts at

www.hindawi.com
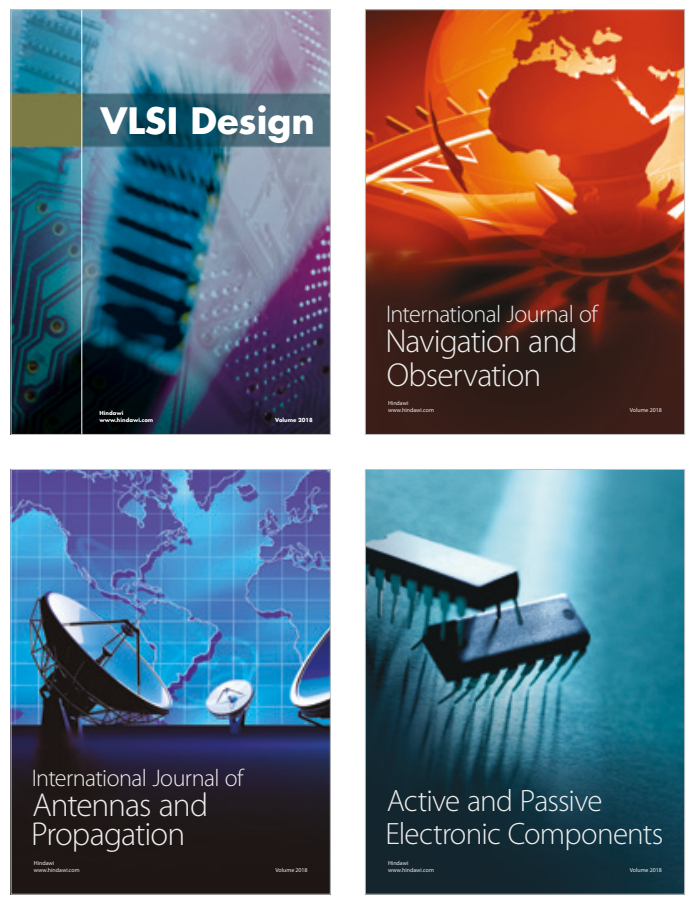
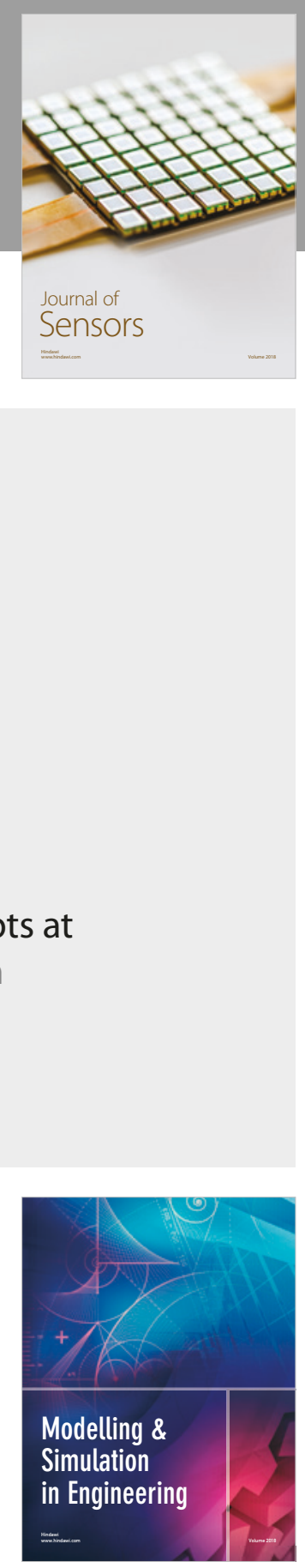

\section{Advances \\ Multimedia}
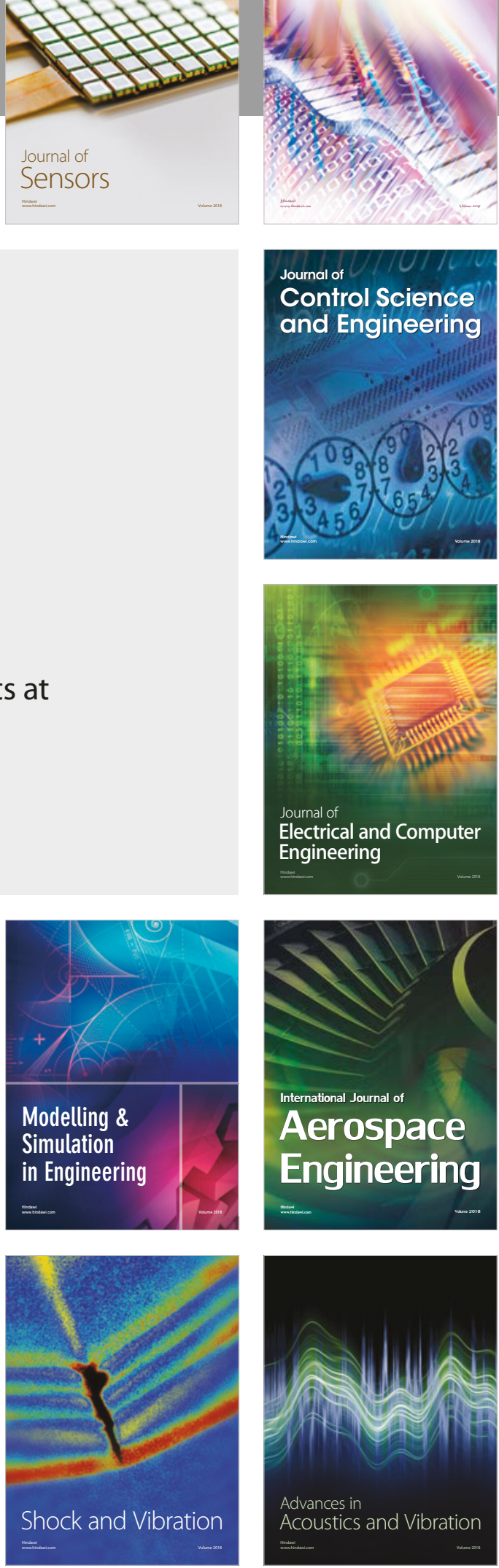